\title{
A Study Comparing Intrinsic Motivation and Opinions on Learning Science (Grades 6) and Taking the International PISA Test (Grade 9)
}

\author{
Moonika Teppo*(D), Regina Soobard (D) and Miia Rannikmäe (D) \\ Centre for Science Education, University of Tartu, 60532 Tartu, Estonia; regina.soobard@ut.ee (R.S.); \\ miia.rannikmae@ut.ee (M.R.) \\ * Correspondence: moonika.teppo@ut.ee
}

Citation: Teppo, M.; Soobard, R.; Rannikmäe, M. A Study Comparing Intrinsic Motivation and Opinions on Learning Science (Grades 6) and Taking the International PISA Test (Grade 9). Educ. Sci. 2021, 11, 14. https://doi.org/10.3390/educsci 11010014

Received: 27 November 2020 Accepted: 28 December 2020 Published: 1 January 2021

Publisher's Note: MDPI stays neutral with regard to jurisdictional clai$\mathrm{ms}$ in published maps and institutional affiliations.

Copyright: (C) 2021 by the authors. Licensee MDPI, Basel, Switzerland. This article is an open access article distributed under the terms and conditions of the Creative Commons Attribution (CC BY) license (https:// creativecommons.org/licenses/by/ $4.0 /)$.

\begin{abstract}
Research findings indicate a decline in students' motivation towards science learning through grade levels. However, there is a lack of studies investigating students' motivation comparing learning between science subjects and at different school levels. Using self-determination theory as a framework, this study compares perceived changes in intrinsic motivation and student opinions on the relevance of learning science themes among students in grades 6 and 9 (the end of compulsory schooling). To explore such learning, a multidimensional validated instrument is developed and used to collect empirical data from 2673 grade 6 students and 848 grade 9 students. Results from this research indicate statistically significant subject differences regarding sub-components of intrinsic motivation and a declining trend in students' opinions on the sub-scales of relevance for learning science themes with age. The results further indicate that grade 6 students report significantly higher science-related intrinsic motivation compared with grade 9 students. Suggestions and implications for practice and the potential impact on PISA science studies are discussed.
\end{abstract}

Keywords: self-determination theory; intrinsic motivation; relevance; students' opinions

\section{Introduction}

Motivation has a significant influence on student's learning and performance [1,2]. Yet studies have shown that there is a decline in student motivation toward science learning going from elementary to secondary school [3-6]. However, previous research has focused on science in general (e.g., [4,6]) or on one science subject (e.g., chemistry [7], physics [8], biology $[9,10]$, geography [11]), but did not distinguish between different science subjects at once in exploring motivation. Age-related trends in students' motivation are largely absent, especially when considering different science subjects (i.e., towards biology, geography, chemistry and physics) at the same time within one research study.

Internationally, science attainment is tested by different bodies (OECD, Organisation for Economic Co-operation and Development and TIMSS, Trends in International Mathematics and Science Study). The science education focussed PISA 2015 assessment, ran by the OECD, focusing on science learning among 15-year-old students was undertaken in 72 countries worldwide [12]. Among the countries participating in PISA, science is taught as separate subjects in a number of these, and in the case of four countries (Estonia, Latvia, Lithuania and Slovenia) these students are in grade 9 (in the current research, the students are within the PISA-defined 15-year-old age group).

Generally, motivation can be divided into two considerations-intrinsic and extrinsic [13]. Intrinsic motivation tends to be equated with satisfaction and meaningfulness i.e., having personal value for the learner [14], whereas in extrinsic motivation, a student's behaviour is more dependent on the value of external factors promoting the relevance of the topic. There is a tendency for intrinsic motivation to decline with advances in science learning, i.e., with age and the ability to deal with more abstract cognition [15], which relate 
to, and are influenced by, both the teaching and the learning environment. In other words, students tend to formulate opinions (in terms of want/wish/like to learn) about their science learning, not only derived from the curriculum/teaching environment, but also from specific experiences in everyday life, or the social environment. With age, students become more familiar with a wider range of science content (and contexts). However, as students' progress through grade levels, there is a tendency for science learning to be split into different science domains, each taught separately. In such situations, it seems that chemistry and physics are perceived to be the least liked subjects, especially when compared with biology [5,16-18], and external motivation fails to stimulate relevance.

Considering the important role that science education plays in the development of society and the economy and the declining numbers of students choosing science and technology-related disciplines and careers [19], the aim of this study is to investigate the level of students' intrinsic motivation and opinions associated with relevance in learning different science subjects and the number of years of schooling. Hence, the present study, adopting a self-determination perspective, investigates students' opinions, in terms of relevance, related to learning science themes, in addition to seeking students' intrinsic motivation, taking into account both grade levels and the learning of science subjects.

The following research questions are put forward:

1. What are the trends from grade 6 to 15 -year-old, grade 9 students' opinions, in terms of relevance (in terms of personal, social and subject preferences) in learning science themes?

2. What differences occur between grade 6 and 15-year-old, grade 9 students' intrinsic motivation and its indicators (interest/enjoyment, perceived competence, effort/importance and value/usefulness) towards learning different science subjects?

\subsection{Motivation and Factors Influencing It}

Motivation is a complex term and has different interpretations, but, generally, motivation refers to an inner process that activates, stimulates, provides direction and maintains behaviour over time [20-23]. This suggests motivation is needed for a change in behaviour to achieve a desired result or goal. Motivation is also related with other psychological concepts, seen as interest/enjoyment, competence, effort and, in addition, self-perceived meaningful learning (value). These constructs have been used in several intrinsic motivation studies based on the Self-Determination Theory (SDT) [13,23,24].

Motivation is believed by researchers and educators to be an important precondition for initiating and maintaining learning, having a positive impact on students' interest and performance. Ryan and Deci [23] have described a motivated person as a person who is stimulated to do something, i.e., he or she is energized or activated to engage in the task or activity. For example, studies have shown that students perform better academically in science if they have higher intrinsic motivation [25]. In addition to higher academic achievement in science, the level of motivation is also dependent on how competent students themselves feel while learning science, how much choice and autonomy they have in the learning, or how meaningful and valuable the science learning is for themselves [13]. In other words, motivation depends very much on how students feel and can self-determine for themselves.

\subsection{Intrinsic Motivation and Related Constructs in Terms of Self-Determination Theory (SDT)}

A widely referenced theory is Self-Determination Theory (SDT) [23], although others have been put forward, e.g., Achievement goal theory [26] and Expectancy-value theory [27]. SDT relates to human motivation, development of personality and behavioural self-determination, distinguishing intrinsic and extrinsic types of motivation, based on the different reasons or goals that give rise to an activity [23]. Intrinsic motivation refers to doing something for itself, giving pleasure, interest and satisfaction derived from the performance [13]. In other words, an intrinsically motivated person gets reward and enjoyment from the performance or activity itself. Extrinsic motivation, however, refers to behaviour 
that is driven by external factors, such as grades, praise, or attention [13,23]. Based on SDT, Ryan and Deci $[13,23]$ propose that when learning is satisfying and meaningful, it is perceived to be of value by the learner. In other words, when students recognize purpose and develop confidence, the motivation is intrinsic and has the potential to enhance learning from different perspectives.

Interest/enjoyment is considered to be a self-reported measure of intrinsic motivation, based on SDT [13]. Both interest and enjoyment belong to the affective domain; thus, in the current study, these are taken as synonyms, although they have different determinants. For example, Reeve [28] concludes that "interest contributes to intrinsic motivation by arousing the initiation and direction of attention and exploratory behaviour, while enjoyment contributes to intrinsic motivation by sustaining the willingness to continue and persist in the activity". Studies have indicated the importance of interest/enjoyment in successful learning and achievement [29,30].

Intrinsic motivation is influenced by perceived competence, which refers to the need of the individuals to experience opportunities and support for the activity and their ability to express their knowledge, skills, abilities, or talents [24]. Furthermore, according to social-cognitive theory, people are motivated to learn if they believe that they can achieve the desired results [31]. In other words, if students perceive themselves to be sufficiently competent while undertaking an activity (i.e., perceive themselves to be good at science, are satisfied with their performance), then they also have a higher intrinsic motivation towards learning. Therefore, perceived competence is considered a very strong predictor of both academic performance and intrinsic motivation.

Effort is also seen as an important factor influencing students' academic performance [32,33]. Effort is defined "as voluntary behaviour or personal investment that a student makes for their education" [34]. They highlight the need to investigate student effort in terms of its intensity and quality, because it depends on how much students work on completing the learning task, or activity. In addition, significant relationships have also been found between academic performance, intrinsic motivation and perceived effort [32]. For example, a study by [35] indicates that students who lack motivation put in less effort, which in turn leads to poor academic performance.

Value/usefulness in the SDT framework is related with the idea that people internalize and become self-regulating with respect to activities that they experience as useful or valuable for themselves [23]. Research indicates that when the science instruction is focused on usefulness and meaningfulness, students are more highly motivated and interested in learning science topics [26,36-38].

\subsection{Intrinsic Motivation Measures}

Self-Determination Theory (SDT) provides the framework for an Intrinsic Motivation Inventory (IMI) [39], which has be used to assess participants' self-reported interest/enjoyment, perceived competence, effort, value/usefulness, felt pressure and tension, plus perceived choice and relatedness, while performing a given activity (subjective experiences related to target activity). IMI has been implemented in different contexts and with different sub-scales in science education research [8,40-43]. For example, Meyer et al. [42] has investigated the impact of choice on aspects of motivation during biology lessons and has found that students who are given the possibility to choose topics in biology lessons have higher levels of intrinsic motivation than students who are not given this option. In their study, Teppo et al. [43] compared grade 6 students' motivation towards science and mathematics and have found that students' interest/enjoyment, perceived competence and choice scores towards learning science are significantly higher than towards mathematics, but at the same time students value and put more effort into mathematics rather than science learning. 


\subsection{Student Opinions (Associated with Relevance)}

Exploring students' opinions about science learning can give meaningful insights on the relevance of the learning, measured by asking students' what they want to know about, what they like, or the relevance of the science theme $[44,45]$. This usually means that which is personally relevant for the student. However, personal relevance can be addressed at different levels. For example, Prinski et al. [14] define relevance as a "personally meaningful connection to the individual" and put forward three types of relevance indicated as: personal associations, personal usefulness and identification, where the first type is the least and the third is the most personally meaningful type of relevance. They further propose that these three types are not mutually exclusive, and each is associated with a high degree of subjectivity, i.e., different stimuli (topics, activities, objects) can elicit different types of relevance at different times. Thus, personal association can be difficult to identify, because students hold diverse opinions and hence, in terms of relevance, can perceive experience differently in an everyday activity [46]. This suggests that while science content can be designed with the intention of being relevant to all students in a particular theme, or activity, it may not have such relevance in practice, because of differing student preferences. In addition to personal/individual relevance, two further dimensions of relevance can also be considered [47] — the societal (focuses on knowledge and skills for societal participation) and vocational (future professions and careers) viewpoints. Both have been proposed as attributes that can make science learning relevant. Studies, in fact, have shown that when the science content is presented in everyday, or social, contexts, it increases students' relevance towards science learning [38,48].

Little is said about subject relevance, as this is generally outside the control of teachers, it being designated in the school, or country curriculum, with little room for teacher control over content. Generally, science subject learning is seen as essential not only because of being integral to everyday life, but also in its contribution to promoting key competences, especially logical thinking associated with cause and effect, promoting approaches to problem solving and decision-making skills, as well as enhancing creative thinking. However, the approach to such development needs to be in line with student cognitive and social development [23] and suitably scaffolded for meaningful learning [49]. Subject relevance in science subjects can be seriously curtailed if the subject demands are beyond the students' developmental abilities.

\section{Methodology}

\subsection{Sample}

Data were collected as a part of a larger project among lower secondary school students in Estonia. The sample was formed considering both school area/district (city schools, small town schools and other schools) and number of students in each school district (see for more detailed description of sample forming by Pedaste et al. [50]). Altogether, 2673 students in grade 6 (average age 12.6) and 848 students from grade 9 (average age 15.6), from 147 schools across Estonia, completed the questionnaire. Sample size in both grades was considered as being representative against the Estonian grade 6 and 9 population. The sample of grade 6 students was larger, because it was utilized as part of a larger study.

\subsection{Instrument}

The instrument used for the current study consisted of two main sections:

(1) Determining students' opinions on learning science. The instrument was compiled based on instruments from several studies $[37,51,52]$ and involved 36 science sub-themes (content areas as per the curriculum) related to lower secondary school science. These themes were presented in 3 different contexts-personal, social and science curriculum content-related (for a more detailed description, see [38]). Themes were selected based on the compulsory learning content indicated in the National curriculum for basic schools [53]. These core science themes were:

- Features and life processes of plants; 
- Structure and composition of substances;

- Natural disasters and landform formation;

- Energy change, e.g., light and electricity.

(2) Identifying the Intrinsic motivation to learn science at school. With respect to the current study, this section consisted of 4 sub-scales taken from the adapted Intrinsic Motivation Inventory [39] as follows:

- Interest/enjoyment (4 items);

- Perceived competence (4 items);

- Effort/importance (3 items);

- Value/usefulness (5 items).

The items were modified slightly so as to fit the science learning context (i.e., "I enjoy studying in science", "Science learning is very interesting", "It takes a lot of effort from me to understand science"). Grade 6 students answered these items from the point of view of science, whereas the 15-year-old students answered from the perspective of one of the four randomly selected biology, geography, physics or chemistry subjects in each class. Not all 15-year-old students responded to all science subjects, as completion of the whole questionnaire would have potentially introduced student fatigue, leading to response unreliability.

All statements within the first section of the instrument were presented using a 4-point Likert scale (1-not agree to 4-totally agree) and, within the second section, based on a 5-point Likert scale (1-strongly disagree, 2-disagree, 3-neither agree nor disagree, 4-agree, 5-strongly agree).

\subsection{Reliability and Validity}

An initial pilot study was carried out by asking one class of grade 6 students and another of grade 9 students to provide feedback on the clarity and understandability of the items. Based on the students' responses, minor changes were made regarding the wording of some items. Different experts were involved in validating the selected themes for the first section of instrument. Interviews with three experts (science education professor, researcher and science teacher) were held to ascertain whether the themes were appropriate to use in both grades and also gave reasonable coverage of the Estonian science curricula. Agreement among expert opinions was $85 \%$, indicating that the themes included in the questionnaire were suitable for use in grades 6 and 9. Cronbach's alpha values, as an estimate of reliability, were calculated for the whole instrument, as well as for the different sub-scales (factors), indicating the reliability coefficient was acceptable at a very appropriate level, ranging from 0.70 to 0.94 in both grades. Internal consistency for the first, "opinions" section was 0.97 and 0.97 for grade 6 and 9, respectively, and for the "intrinsic motivation" scale, 0.92 and 0.93 , respectively. An alpha coefficient $\geq 0.70$ is considered to be an acceptable value [54,55].

\subsection{Data Collection}

The questionnaire was administered electronically either using school computers, or tablet computers provided by a data collector responsible for implementing the survey at a school. Students answered the questionnaire during a regular science lesson. It took approximately 10-15 $\mathrm{min}$ to complete the two-sections questionnaire.

\subsection{Data Analysis}

SPSS Statistics 26 and Mplus (version 8.4; [56]) were used for data analysis. At first, descriptive statistics (means, standard deviations) of items in both sections were calculated. In order to investigate the internal structure of the instrument, factor analysis was applied. Because the first section of the instrument (Opinions on learning science themes) was developed by the authors, first exploratory factor analysis (EFA) was carried out to determine the factor structure of this section and to detect problematic items separately, within grade 6 and 9. Principal axis factoring (PAF) with a direct oblimin rotation was conducted, limiting 
the solution to factors with eigenvalues greater than one. The Kaiser-Meyer-Olkin (KMO) measure of sampling adequacy and Bartlett's tests for sphericity were used in order to determine whether the principal axis factor analysis was appropriate for these datasets.

Confirmatory factor analysis (CFA) was used to test the factorial structure of both sections of the instrument. To evaluate the goodness of fit of models, well-established indices and their criteria were used as follows: the Tucker-Lewis Index (TLI $\geq 0.90$ ), the Comparative Fit Index $(\mathrm{CFI} \geq 0.90)$ and the Root Mean Square Error of Approximation $(0.03<$ RMSEA < 0.08) [54].

To compare grade differences between 6 and 9 students and subjects' differences (biology, geography, physics and chemistry) within grade 9 , regarding both sections of the instrument, a non-parametric Mann-Whitney $U$-test was conducted.

\section{Results and Interpretation}

\subsection{Descriptive Statistics}

The first section includes items related with students' opinions about learning different science themes. The mean values are between 2.27 to 3.00 and 2.12 to 2.94 , respectively, among grade 6 and 9 students (Table 1). The results show that the most positive opinions on science themes (mean value above 2.5) related to everyday life, or social issues, for both grades, while, in grade 6 , average values are somewhat higher compared with those corresponding in grade 9 . For example, the results indicate that the most relevant themes for both grades are related with natural disasters, followed by poisonous plants. On the contrary, the least relevant themes (mean value below 2.5) are inherently related to abstract science content, or its application (chemical composition of water, methods of plant reproduction and propagation, atoms and molecules as the smallest particles of the substance, etc.). The standard deviation values are approximately 1.00, meaning that students indicated quite a large variety in their choices.

Within the second section, mean values within both grades are all above 3.00 (except reversed items), indicating generally positive perceptions towards science learning (Table 2). It is seen that grade 6 students indicate the most positive mean values associated with their learning competence (e.g., I am satisfied with my performance; I am good at learning science), while the lowest mean values are related to the need to exert effort to understand science. Within the 15-year-old, grade 9 students, the tendencies are quite similar, although students' opinions about chemistry and physics learning are somewhat lower, compared with those from biology and geography. For example, students perceive the chemistry, physics and geography themes to be less relevant compared with biology. In addition, the 15-year-old students perceive learning chemistry and activities in chemistry lessons as the least appropriate in their everyday life, as well as feeling themselves to be less competent and thus making less effort in chemistry learning. At the same time, these students feel themselves to be the most competent, and therefore perceive the most value, in biology and geography learning at school. The standard deviations range from 0.89 to 1.26 , indicating that students' preferences vary to a significant extent. 
Table 1. Mean values and standard deviations of the items related with grade 6 and 9 students' opinions on learning science themes.

\begin{tabular}{|c|c|c|c|c|c|}
\hline & \multirow{2}{*}{ Themes } & \multicolumn{2}{|c|}{ Grade $6(N=2673)$} & \multicolumn{2}{|c|}{ Grade $9(N=848)$} \\
\hline & & $M$ & $S D$ & $M$ & $S D$ \\
\hline $\mathrm{T} 1$ & I would like to study the external structure, reproduction, growth and distribution characteristic of different plant groups. & 2.34 & 0.96 & 2.29 & 0.96 \\
\hline $\mathrm{T} 2$ & I want to learn about atoms and molecules as smaller particles of matter. & 2.38 & 1.02 & 2.23 & 0.99 \\
\hline $\mathrm{T} 4$ & I want to know more about poisonous plants to distinguish between healing and lethal amounts. & 2.89 & 0.97 & 2.81 & 0.95 \\
\hline T5 & I wish to know more about natural disasters-earthquakes, floods, storms. & 3.00 & 0.95 & 2.94 & 0.91 \\
\hline T6 & I would like to study the effects of the atomic structure of metals on their chemical and physical properties. & 2.42 & 1.04 & 2.17 & 0.97 \\
\hline T7 & I want to know more about how the continental ice has shaped the sights of my hometown. & 2.56 & 0.99 & 2.38 & 0.96 \\
\hline T8 & I wish to know why it is necessary to use a water softener to prolong the life of household appliances. & 2.37 & 1.01 & 2.33 & 0.95 \\
\hline T10 & I want to know more about the weather conditions in which a rainbow occurs. & 2.57 & 1.01 & 2.43 & 0.94 \\
\hline T11 & I would like to learn how the intensity of photosynthesis affects the plants growing in a greenhouse. & 2.31 & 1.01 & 2.31 & 0.99 \\
\hline T12 & I would like to study the construction of the metal atom to decide on the safety and security of building structures. & 2.33 & 1.03 & 2.12 & 0.98 \\
\hline T13 & I want to know more about poisonous plants and their characteristics. & 2.77 & 1.01 & 2.61 & 0.98 \\
\hline T14 & I would like to learn how the process of forming different landforms affects their characteristics. & 2.29 & 1.00 & 2.26 & 0.94 \\
\hline T15 & I wish to know how various natural disasters affect the development of tourism. & 2.69 & 1.01 & 2.60 & 0.97 \\
\hline T16 & I wish to know the chemical composition of domestic water. & 2.46 & 1.02 & 2.29 & 0.97 \\
\hline T17 & I would like to know more about the relationship between the composition of a detergent and its effectiveness in washing laundry. & 2.27 & 1.00 & 2.23 & 0.96 \\
\hline T18 & I would like to learn how the structure of flowering plant organs depends on their functions. & 2.30 & 1.01 & 2.23 & 0.96 \\
\hline T19 & I would like to study the electric circuit and its parts. & 2.32 & 1.01 & 2.29 & 0.97 \\
\hline $\mathrm{T} 22$ & I want to study landforms shaped by continental ice (rounds, hills) & 2.30 & 1.00 & 2.15 & 0.92 \\
\hline $\mathrm{T} 23$ & I wish to know how the climate affects the occurrence of natural disasters & 2.80 & 1.00 & 2.70 & 0.96 \\
\hline $\mathrm{T} 24$ & I would like to know more about the impact of restrictions on the extraction of natural resources on the preservation of natural attractions. & 2.47 & 1.02 & 2.39 & 0.96 \\
\hline $\mathrm{T} 25$ & I wish to know more about the chemical properties of detergents (soap, washing powder). & 2.26 & 1.01 & 2.14 & 0.94 \\
\hline T26 & I wish to find out the connection between a slippery road and the wrong speed. & 2.47 & 1.00 & 2.42 & 0.95 \\
\hline $\mathrm{T} 27$ & I want to learn more about the uses of lasers in entertainment to assess their potential impact on vision. & 2.68 & 1.01 & 2.47 & 0.98 \\
\hline $\mathrm{T} 28$ & I wish to know ways in which plants grow and spread in my hometown. & 2.32 & 1.00 & 2.24 & 0.98 \\
\hline T29 & I want to know more about poisonous plants and their effects on the body. & 2.76 & 1.03 & 2.64 & 0.99 \\
\hline T30 & I would like to know how energy labelling of household appliances affects electricity consumption. & 2.38 & 1.00 & 2.22 & 0.94 \\
\hline $\mathrm{T} 31$ & I would like to learn how surface affects agricultural income. & 2.27 & 0.99 & 2.19 & 0.92 \\
\hline T32 & I want to know more about the natural sights of my hometown. & 2.61 & 1.01 & 2.47 & 0.97 \\
\hline T33 & I wish to know that the salinity of water depends on in different parts of the world. & 2.53 & 1.01 & 2.39 & 0.97 \\
\hline T34 & I would like to know more about the reliability of the information provided in detergent ads. & 2.31 & 1.05 & 2.29 & 0.98 \\
\hline T35 & I want to know more about optical phenomena in the sky. & 2.83 & 1.01 & 2.65 & 0.98 \\
\hline T36 & I would like to know which household appliances to prefer to save electricity. & 2.43 & 1.03 & 2.37 & 0.98 \\
\hline
\end{tabular}


Table 2. Mean values and standard deviations of the items within the intrinsic motivation section among grade 6 and 9 students.

\begin{tabular}{|c|c|c|c|c|c|c|c|c|c|c|}
\hline \multirow{3}{*}{ Items } & \multirow{2}{*}{\multicolumn{2}{|c|}{$\begin{array}{c}\text { Grade } 6 \\
\text { Science } \\
(N=2673)\end{array}$}} & \multicolumn{8}{|c|}{ Grade $9(N=848)$} \\
\hline & & & \multicolumn{2}{|c|}{$\begin{array}{c}\text { Biology } \\
(N=220)\end{array}$} & \multicolumn{2}{|c|}{$\begin{array}{c}\text { Geography } \\
(N=216)\end{array}$} & \multicolumn{2}{|c|}{$\begin{array}{l}\text { Physics } \\
(N=192)\end{array}$} & \multicolumn{2}{|c|}{$\begin{array}{c}\text { Chemistry } \\
(N=220)\end{array}$} \\
\hline & $M$ & $S D$ & $M$ & $S D$ & $M$ & $S D$ & $M$ & $S D$ & $M$ & $S D$ \\
\hline \multicolumn{11}{|l|}{ Interest/enjoyment ( $\alpha=0.93$ for grade $6 ; \alpha=0.93$ for grade 9 ). } \\
\hline I enjoy doing science very much. & 3.45 & 1.12 & 3.45 & 1.11 & 3.19 & 1.04 & 3.20 & 1.20 & 3.06 & 1.13 \\
\hline I think learning science is fun. & 3.49 & 1.12 & 3.52 & 1.09 & 3.23 & 1.06 & 3.17 & 1.20 & 3.11 & 1.18 \\
\hline I think learning science is boring $(\mathrm{R})$. & 2.48 & 1.18 & 2.47 & 1.14 & 2.69 & 1.07 & 2.81 & 1.23 & 2.74 & 1.23 \\
\hline \multicolumn{11}{|l|}{ Perceived competence ( $\alpha=0.92$ for grade $6 ; \alpha=0.94$ for grade 9 ). } \\
\hline I think I am pretty good at learning science. & 3.91 & 0.94 & 3.83 & 0.95 & 3.80 & 0.93 & 3.55 & 1.01 & 3.33 & 1.16 \\
\hline After having learned science for a while, I feel pretty competent. & 3.88 & 0.96 & 3.81 & 0.89 & 3.79 & 0.96 & 3.45 & 1.10 & 3.24 & 1.19 \\
\hline I am satisfied with my performance in science. & 3.92 & 0.98 & 3.82 & 0.92 & 3.79 & 1.02 & 3.47 & 1.11 & 3.28 & 1.21 \\
\hline I know science very well. & 3.80 & 0.99 & 3.75 & 0.89 & 3.69 & 1.00 & 3.31 & 1.07 & 3.24 & 1.19 \\
\hline \multicolumn{11}{|l|}{ Effort/importance ( $\alpha=0.70$ for grade $6 ; \alpha=0.76$ for grade 9 ). } \\
\hline It takes a lot of effort from me to understand science. & 3.12 & 1.12 & 2.90 & 1.05 & 2.84 & 1.02 & 3.24 & 1.11 & 3.10 & 1.11 \\
\hline It is important for me to study science well. & 3.66 & 1.06 & 3.44 & 1.14 & 3.38 & 1.07 & 3.52 & 1.09 & 3.38 & 1.17 \\
\hline \multicolumn{11}{|l|}{ Value/usefulness ( $\alpha=0.84$ for grade $6 ; \alpha=0.87$ for grade 9 ). } \\
\hline Learning activities in science lessons are useful. & 3.83 & 1.01 & 3.69 & 1.05 & 3.74 & 0.89 & 3.67 & 1.00 & 3.38 & 1.11 \\
\hline What I have learned in science class can be useful to me solving different problems. & 3.56 & 1.06 & 3.70 & 1.00 & 3.58 & 0.96 & 3.61 & 1.05 & 3.30 & 1.08 \\
\hline Participating in science lessons is useful for me, because I am learning new knowledge and skills. & 3.88 & 0.99 & 3.81 & 1.00 & 3.71 & 0.93 & 3.64 & 1.07 & 3.41 & 1.11 \\
\hline In science lessons I learn things, which are not needed in real life (R). & 2.56 & 1.09 & 2.47 & 1.05 & 2.56 & 1.01 & 2.77 & 1.08 & 2.84 & 1.13 \\
\hline I can apply knowledge and skills learned from science lessons in real life. & 3.73 & 1.09 & 3.70 & 1.14 & 3.71 & 0.97 & 3.44 & 1.16 & 3.19 & 1.12 \\
\hline
\end{tabular}

Note: R-reversed items. 


\subsection{Exploratory Factor Analysis on Student Opinions about Learning Science Themes Section}

The Exploratory factor analysis (EFA) was used to investigate the factor structure of the total set of items (36), in order to identify the underlying variables and reduce them to a smaller number. EFA was applied because of having no clear factorial structure. Results from the scree plot were used to determine the number of factors to retain. Analysis indicated that between 2 and 3 factors could be relevant within both grades.

An initial factor matrix for two- and three-factor solutions indicated that there were several items that had low loadings (below 0.40). For example, among the two-factor solution, item T27 within grade 6 students-and, among the three-factor solution, items T10, T21, T27 within grade 6 and items T8, T10, T27, T29, T32, T33, T35 (Table 1) within grade 9-students had low loadings with the corresponding factor and were thus considered for elimination from future analysis. In the second round of EFA, the items with low loadings were removed and factor analysis was carried out with the remaining items, separately, among grade 6 and 9 students. Although two- and three-factor solutions were initially conducted, it was decided to carry out further analysis using the two-factor solutions within both grades, as the factor structure seemed more logical and essentially more easily interpretable, although the three-factor solution explained the variance approximately $5 \%$ more.

The KMO measure of sampling adequacy was 0.98 and 0.97 for the two-factor solutions within grades 6 and 9, indicating adequate values [57]. The Bartlett's test of sphericity was significant with respect to a two-factor solution, $(\chi 2(595)=71,712.49, p<0.001$ and $\chi 2(630)=22,929.46, p<0.001)$ respectively, suggesting a high likelihood of successful factor extraction. The cumulative variance of the two-factor models explained, altogether, $58.1 \%$ and $55.7 \%$ of the variance, respectively, among grade 6 and 9 students, which was considered good, although the first factor described most of the variability.

\subsection{Factor Interpretation in the Opinion's Section}

Table 3 gives an overview of the two-factor solution among both grades. The first factor can be taken to measure students' opinions on school science content-related themes, so it is named as the school science subject relevance factor. This factor includes items related with typical science themes, taught in lower secondary school science, such as the formation of different landforms, chemical properties of substances (detergents), atoms and molecules, atomic structure and chemical bonding, as well as photosynthesis and the structure and functions of plant organs. The second factor appears to measure students' opinions on everyday-life related science themes, i.e., a personal and social relevance factor. These themes are inherently more related with students' personal relevance, the relevance of social problems, or the relevance of natural phenomena in the world, e.g., "I am of the opinion that I wish to know about natural disasters", "I would like to know more about poisonous plants and its influence on the body" and "I am of the opinion that I wish to know the importance of plants in nature and human life". The results indicate that the content of both factors is quite similar within both grades; specifically, there are four items that are different within the first factor and three items that differ within the second factor. Comparing the factors and average mean scores of the items within the factors, it is seen that the everyday-life related science topics factor includes items that have mean scores generally above 2.5 in both grades (except three items among grade 9 students), indicating that students find the topics relevant and would like to know more. 
Table 3. Pattern matrix for the two-factor solution from the second round of EFA (exploratory factor analysis) within grade 6 (left) and 9 students (right).

\begin{tabular}{|c|c|c|c|c|c|}
\hline \multirow{2}{*}{ Items } & \multicolumn{2}{|c|}{ Factors (Grade 6) } & \multirow{2}{*}{ Items } & \multicolumn{2}{|c|}{ Factors (Grade 9) } \\
\hline & 1 & 2 & & 1 & 2 \\
\hline $\mathrm{T} 25$ & 0.90 & & T12 & 0.90 & \\
\hline Т30 & 0.87 & & $\mathrm{~T} 6$ & 0.87 & \\
\hline T31 & 0.85 & & $\mathrm{~T} 25$ & 0.81 & \\
\hline T17 & 0.84 & & $\mathrm{~T} 2$ & 0.80 & \\
\hline T36 & 0.82 & & T30 & 0.75 & \\
\hline T18 & 0.80 & & T19 & 0.75 & \\
\hline T28 & 0.78 & & T16 & 0.73 & \\
\hline T19 & 0.75 & & T17 & 0.71 & \\
\hline T11 & 0.74 & & T36 & 0.60 & \\
\hline T16 & 0.73 & & T18 & 0.58 & \\
\hline $\mathrm{T} 8$ & 0.73 & & $\mathrm{~T} 8$ & 0.55 & \\
\hline T14 & 0.73 & & T31 & 0.53 & \\
\hline T12 & 0.72 & & T11 & 0.53 & 0.33 \\
\hline $\mathrm{T} 26$ & 0.67 & & $\mathrm{~T} 14$ & 0.51 & 0.35 \\
\hline T22 & 0.67 & & $\mathrm{~T} 27$ & 0.50 & \\
\hline T34 & 0.66 & & T34 & 0.50 & \\
\hline T9 & 0.64 & & $\mathrm{~T} 28$ & 0.49 & 0.34 \\
\hline $\mathrm{T} 2$ & 0.60 & & T9 & 0.49 & \\
\hline $\mathrm{T} 1$ & 0.60 & & $\mathrm{~T} 26$ & 0.48 & \\
\hline $\mathrm{T} 24$ & 0.60 & & T33 & 0.47 & 0.37 \\
\hline $\mathrm{T} 21$ & 0.59 & & $\mathrm{~T} 24$ & 0.45 & 0.37 \\
\hline T33 & 0.58 & & $\mathrm{~T} 22$ & 0.42 & 0.39 \\
\hline T6 & 0.58 & & $\mathrm{~T} 1$ & 0.42 & 0.34 \\
\hline T32 & 0.52 & & $\mathrm{~T} 4$ & & 0.77 \\
\hline $\mathrm{T} 10$ & 0.46 & & $\mathrm{~T} 23$ & & 0.77 \\
\hline T5 & & 0.85 & $\mathrm{~T} 5$ & & 0.75 \\
\hline $\mathrm{T} 4$ & & 0.76 & $\mathrm{~T} 15$ & & 0.73 \\
\hline $\mathrm{T} 23$ & & 0.68 & $\mathrm{~T} 13$ & & 0.67 \\
\hline T13 & & 0.66 & $\mathrm{~T} 20$ & & 0.63 \\
\hline T15 & & 0.59 & T29 & & 0.61 \\
\hline T29 & & 0.53 & T3 & & 0.60 \\
\hline $\mathrm{T} 3$ & & 0.46 & $\mathrm{~T} 10$ & & 0.51 \\
\hline $\mathrm{T} 7$ & 0.40 & 0.42 & $\mathrm{~T} 7$ & & 0.50 \\
\hline T20 & & 0.42 & T32 & & 0.48 \\
\hline T35 & & 0.40 & $\mathrm{~T} 21$ & 0.35 & 0.47 \\
\hline & & & T35 & & 0.42 \\
\hline Cumulative \% & 53.1 & 58.1 & Cumulative \% & 50.1 & 55.7 \\
\hline Cronbach alpha & 0.97 & 0.92 & Cronbach alpha & 0.96 & 0.93 \\
\hline
\end{tabular}

Note: Coefficients $<0.30$ are suppressed and not shown for clarity.

\subsection{Confirmatory Factor Analysis}

CFA was used to determine the factor structure of both instrument sections to determine whether the items could distinguish between the following:

(1) Two factors (sub-scales) based on EFA regarding students' opinions on learning science themes (Section 1);

(2) The four sub-scales of interest/enjoyment, perceived competence, effort/importance and value/usefulness, related with the intrinsic motivation scale (Section 2).

First-order CFA analyses were conducted within both sections to estimate construct validity, i.e., how the observed items loaded into the corresponding factors (sub-scales) separately among both grades.

The results from Table 4 showed that the initial two-factor measurement model within section one gave poor fit indices within both grades (TLI < 0.90, CFI < 0.90). The reason 
could be related to the high correlations between the two factors $(r>0.80)$, indicating that the factors were essentially quite similar. Nevertheless, the two factors were retained, because EFA indicated adequate values for the two-factor solution. Within the intrinsic motivation section, CFA was used to confirm the four-factor structure. The results showed good fit indices in both grades (TLI, CFI and RMSEA were acceptable according to Hair et al. [54]), indicating good construct validity.

Table 4. Summary of the goodness of fit indices for different CFA (confirmatory factor analysis) models.

\begin{tabular}{cccccccc}
\hline Models & Grade & $\chi \chi^{2}$ & $d f$ & $p$ & CFI & TLI & RMSEA \\
\hline \multirow{2}{*}{ 2-factor model of students' opinions } & 6 & $10,234.98$ & 559 & $<0.001$ & 0.87 & 0.86 & 0.08 \\
& 9 & 4926.37 & 593 & $<0.001$ & 0.81 & 0.80 & 0.09 \\
\hline \multirow{2}{*}{ 4-factor model of intrinsic motivation } & 6 & 1251.49 & 98 & $<0.001$ & 0.96 & 0.95 & 0.07 \\
& 9 & 547.93 & 98 & $<0.001$ & 0.96 & 0.95 & 0.07 \\
\hline
\end{tabular}

3.5. Grade and Subject Differences in Students' Opinions on Learning Science Themes and Their Intrinsic Motivation

Descriptive statistics and the Mann-Whitney $U$-test are used to determine whether there are statistically significant differences between the sub-scales among grades and science subjects. As there are two items ("I think learning science is boring" and "In science lessons I learn things, which are not needed in real life") within the intrinsic motivation scale, which are presented in reverse order, these statements are reversed prior to the group comparison $(1=5,2=4,3=3,4=2,5=1)$.

Table 5 shows that students in grade 6 have generally higher mean ratings within all sub-scales compared with grade 9. However, students' opinions on learning science themes (grade 6) in the sub-scales (two factors as latent variables) are not comparable with those for grade 9 , as the content of the factors is not identical. Despite this, it is seen that, generally, grade 6 students indicate higher ratings on learning science themes compared with grade 9, especially towards everyday life-related contexts, i.e., related to plants and natural disasters.

On the other hand, there are significant group differences, between grades 6 and 9 and within grade 9 science subjects, related to intrinsic motivation. Specifically, students' interest/enjoyment towards science (in grade 6) and biology (in grade 9) are most positive $(M=3.47$ and $M=3.49$, respectively) compared with those in geography, chemistry and physics (grade 9). Furthermore, Table 5 shows that significant differences appear, given by the Mann-Whitney $U$-test, between outcomes for science (grade 6) with:

- $\operatorname{Geography}(z=-3.93, p<0.001)$ (grade 9);

- $\quad$ Chemistry $(z=-4,41, p<0.001)$ (grade 9);

- $\operatorname{Physics}(z=-3.63, p<0.001)$ (grade 9).

In addition, at a significance level $(p<0.05)$ within grade 9 , significant differences appear between:

- Biology and geography $(z=-3.00, p<0.05)$, chemistry $(z=-3.40, p<0.05)$ and physics $(z=-2.98, p<0.05)$;

- $\quad$ Geography and chemistry $(z=-3.40, p<0.05)$. 
Table 5. Comparison of grade 6 and 9 students' opinions on learning science themes and their intrinsic motivation towards science learning.

\begin{tabular}{|c|c|c|c|c|c|c|c|}
\hline \multirow[b]{2}{*}{$\begin{array}{l}\text { Science } \\
\text { Subject }\end{array}$} & & \multicolumn{2}{|c|}{ Opinions on Learning Science Themes } & \multicolumn{4}{|c|}{ Intrinsic Motivation } \\
\hline & & $\begin{array}{c}\text { School Science } \\
\text { Subject Relevance } \\
\text { Topics }\end{array}$ & $\begin{array}{c}\text { Personal and } \\
\text { Social Relevance }\end{array}$ & $\begin{array}{l}\text { Interest/ } \\
\text { Enjoyment }\end{array}$ & $\begin{array}{l}\text { Perceived } \\
\text { Competence }\end{array}$ & $\begin{array}{c}\text { Effort/ } \\
\text { Importance }\end{array}$ & $\begin{array}{c}\text { Value/ } \\
\text { Usefulness }\end{array}$ \\
\hline \multirow{2}{*}{$\begin{array}{c}\text { Science } \\
(N=2673)\end{array}$} & Mean & 2.37 & 2.77 & 3.47 & 3.88 & 3.43 & 3.69 \\
\hline & $S D$ & 0.76 & 0.75 & 1.02 & 0.86 & 0.86 & 0.82 \\
\hline \multirow{2}{*}{$\begin{array}{l}\text { Biology } \\
(N=220)\end{array}$} & Mean & 2.29 & 2.63 & 3.49 & 3.68 & 3.19 & 3.69 \\
\hline & $S D$ & 0.74 & 0.75 & 1.02 & 0.78 & 0.89 & 0.87 \\
\hline \multirow{2}{*}{$\begin{array}{l}\text { Geography } \\
(N=216)\end{array}$} & Mean & 2.19 & 2.54 & 3.22 & 3.65 & 3.12 & 3.64 \\
\hline & $S D$ & 0.67 & 0.66 & 0.97 & 0.82 & 0.86 & 0.75 \\
\hline \multirow{2}{*}{$\begin{array}{l}\text { Chemistry } \\
(N=220)\end{array}$} & Mean & 2.31 & 2.63 & 3.14 & 3.20 & 3.22 & 3.29 \\
\hline & $S D$ & 0.72 & 0.72 & 1.08 & 1.04 & 0.96 & 0.88 \\
\hline \multirow{2}{*}{$\begin{array}{l}\text { Physics } \\
(N=192)\end{array}$} & Mean & 2.28 & 2.66 & 3.17 & 3.33 & 3.36 & 3.52 \\
\hline & $S D$ & 0.70 & 0.64 & 1.06 & 0.93 & 0.91 & 0.86 \\
\hline \multirow{10}{*}{$\begin{array}{l}\text { Group } \\
\text { difference, } \\
\text { z-statistics }\end{array}$} & Bio-Geo & -1.64 & -1.70 & $-3.00 *$ & -0.02 & -0.60 & -0.95 \\
\hline & Bio-Chem & -0.18 & -0.15 & $-3.40 *$ & $-4.52 * *$ & -0.79 & $-4.86^{* *}$ \\
\hline & Bio-Phys & -0.60 & -0.18 & $-2.98 *$ & $-3.55^{* *}$ & -1.93 & $-2.11 *$ \\
\hline & Geo-Phys & -1.01 & -1.75 & -0.13 & $-3.47^{*}$ & $-2.56 *$ & -1.33 \\
\hline & Geo-Chem & -0.19 & -0.15 & $-3.40 *$ & $-4.52 * *$ & -0.79 & $-4.86^{* *}$ \\
\hline & Chem-Phys & -0.71 & -0.14 & -0.36 & -1.04 & -1.14 & $-2.78 *$ \\
\hline & Sci-Bio & n. a & n. a & -0.27 & -0.96 & $-3.93^{* *}$ & -0.25 \\
\hline & Sci-Geo & n. a & n. a & $-3.93 * *$ & -0.98 & $-4.83^{* *}$ & -1.08 \\
\hline & Sci-Chem & n. a & n. a & $-4.41^{* *}$ & $-6.92^{* *}$ & $-2.70 *$ & $-6.54^{* *}$ \\
\hline & Sci-Phys & n. a & n. a & $-3.63 * *$ & $-5.45^{* *}$ & -1.05 & $-2.63 *$ \\
\hline
\end{tabular}

Note: Bio—biology, Geo—geography, Chem—chemistry, Phys—physics, Sci-science. $z$-statistics determined by the Mann-Whitney $U$-test. ${ }^{*} p<0.05 ;{ }^{* *} p<0.001 ;$ n. a-not applicable.

Table 5 further shows that students perceive themselves to be more competent in learning science $(M=3.88$; grade 6$)$, biology and geography $(M=3.68$ and $M=3.65$, respectively), but not so much in chemistry and physics ( $M=3.20$ and $M=3.33$, respectively) (grade 9). This is illustrated by the statistically significant differences between subjects. For example, differences appear between sciences (grade 6) with:

- Chemistry $(z=-6.92, p<0.001)$ and physics $(z=-5.45, p<0.001)$ (grade 9).

Furthermore, for 15-year-old students in grade 9, differences also appear between:

- Biology and chemistry $(z=-4.52, p<0.001)$ and physics $(z=-3.55, p<0.001)$;

- Geography and chemistry $(z=-4.52, p<0.001)$ and physics $(z=-3.47, p<0.05)$.

There is a perceived trend in that grade 6 students in science $(M=3.43)$ and grade 9 students in physics $(M=3.36)$ indicate the need for more effort/importance compared with learning biology and geography. Subject differences are not so considerable among grade 9 students regarding effort/importance, but are more significant between grade 6 and 9 with respect to:

- $\quad$ Science versus biology $(z=-3.93, p<0.001)$;

- Science versus geography $(z=-4.83, p<0.001)$.

In addition, at a significance level $(p<0.05)$ within grade 9 between:

- Geography and physics $(z=-2.56, p<0.05)$.

In terms of findings associated with value/usefulness, it appears that grade 6 students' feel that science is the most valuable and useful $(M=3.69$; grade 6$)$, as well as biology, geography and physics $(M=3.69, M=3.64, M=3.52$, respectively), compared with chemistry $(M=3.29$, grade 9$)$ in grade 9 .

Differences appear between sciences (grade 6) with:

- Chemistry $(z=-6.54, p<0.001)$ and physics $(z=-2.63, p<0.001)$ (in grade 9).

Differences appear between sciences (grade 9 ) with: 
- Biology and chemistry $(z=-4.86, p<0.001)$ and physics $(z=-2.11, p<0.05)$;

- Geography and chemistry $(z=-4.86, p<0.001)$;

- Chemistry and physics $(z=-2.78, p<0.05)$.

\section{Discussion}

This research focuses on investigating student differences in opinions and intrinsic motivation between grade 6 and grade 9 towards science learning, with consideration of the fact that students learn science themes in grade 6 through one subject, whereas the 15-year-old students in grade 9 learn through separate science subjects (science, biology, geography, chemistry and physics). In the research, students are asked to indicate:

(1) Opinions on learning science themes, (I wish, I want, I like);

(2) Perceived intrinsic motivation (in terms of interest/enjoyment, perceived competence, effort/ importance and value/usefulness) towards learning science subjects.

What are the trends from grade 6 to 15 -year-old grade 9 in terms of students' opinions on the relevance of within subject themes (in terms of personal, social and subject preferences)?

Using exploratory factor analysis for grouping the items, it is shown that it is possible to describe students' opinions related to learning science themes with two latent factors, named as personal and social relevance and also school subject-related relevance. The results reveal that students hold more positive opinions on learning themes that are related to personal and social relevance, rather than abstract science content-related themes. For example, if the science themes are presented in a social and personal context (e.g., natural phenomena, effects of poisonous plants on the body), as compared with chemistry and physics-related themes, presented in an abstract format (e.g., atoms and molecules as the smallest particles of matter, electric circuits), then students' relevance is shown to be higher towards personal and social context-related themes, especially in grade 6 compared with grade 9 . This result is supported by previous research which indicates that students wish to learn about the themes when they perceive them as personally relevant and also when the science content is connected with their experiences in everyday life situations, or with a social context $[38,48,52]$. This suggests that one way to enhance the relevance of science learning for students' in schools is by offering a variety of real-life examples in science learning, i.e., that students see the value of doing something [20]. Not only personal associations and usefulness are important, but the further goal should be reach to the most meaningful type of relevance, i.e., identification that involves perceiving the learning content or context to be part of his or her identity, which is likely to have the strongest influence on motivation, as well as posing more challenges for teaching and learning [14].

Current research also revealed age differences in students' relevance towards learning science themes. The tendency shows a decline in students' opinions with age; in other words, grade 9 students are more negative towards learning science themes, especially those related to school science subject relevance, compared with grade 6 students. This result is consistent with other researchers who have indicated the decline in students' interest/attitudes/motivation towards science [3,5], but not precisely related with students' opinions on relevance (wish/want/like to study) towards learning science themes from primary to secondary school. The current research indicates the need to investigate, in more depth, students' opinions on the relevance of learning in different cultures (countries) especially regarding whether science is taught as one discipline or divided into sub disciplines.

What differences occur between grade 6 and 15-year-old, grade 9 students' intrinsic motivation and its indicators (interest/enjoyment, perceived competence, effort/importance and value/usefulness) towards learning different science subjects?

Research results show that students in grade 6 give, overall, more positive mean ratings towards indicators of intrinsic motivation compared with the 15-year-old students in grade 9 . Specifically, grade 6 students tend to perceive science learning as significantly more interesting/enjoyable and valuable and they feel themselves to be more competent than when 15-year-old students are learning through separate science subjects, related to 
chemistry and physics themes, as is the common practice in many countries (PISA studies indicate this is the case in the majority of countries involved in PISA 2015) [12].

More specifically, the findings show that grade 6 students' intrinsic motivation in learning science and the motivation of 15-year-old students in grade 9 to learn biology and geography have similar tendencies, apart from the intrinsic motivation aspect associated with effort/importance. Such results are in accordance with previous studies, indicating that younger students perceive science to be more motivating [3,4]. In addition, previous research has indicated similar tendencies when comparing different age groups, for example, related to biology $[9,10]$ and chemistry [7] learning.

Table 5 shows student differences in the learning of sub-divisions of science subjects among the 15-year-old, grade 9 students. The most significant differences have emerged between biology or geography and chemistry or physics. For example, significant differences (in terms of intrinsic motivation) between learning biology compared with the subjects of geography, chemistry and physics relate to:

(a) Interest/enjoyment, i.e., biology is perceived to be the most interesting and enjoyable compared with other science subjects. This is in agreement with previous researchers, who have shown that chemistry and physics studies are liked less compared with those in biology [16-18]. For example, a study by Lamanauskas and colleagues [16] has indicated that biology and geography (among Lithuanian and Latvian secondary school students, respectively) are perceived to be the subjects that are liked more, compared with chemistry.

(b) Perceived competence, i.e., biology and geography on the one hand, and chemistry and physics on the other.

(c) Effort/importance is shown to indicate no subject differences except between geography and physics, where students seem to perceive that they put more effort in physics learning compared with other subjects.

Thus, the 15-year-old, grade 9 students perceive themselves to be more competent, good at and satisfied with their performance in biology and geography when compared with chemistry and physics learning. It seems that there are several reasons for this trend, starting from personal interests and knowledge and including teaching and learning approaches used in different science lessons by different teachers, although more detailed research is needed to identify the factors influencing this trend. Furthermore, the 15-yearold, grade 9 students perceive biology, geography and physics learning to be significantly more valuable and useful compared with chemistry. In summary, it became evident that chemistry is the subject which 15-year-old, grade 9 students feel to be of least interest and offering the least enjoyment, and it is perceived by students to be a subject where they have low competence; it is, therefore, valued less compared with other science subjects.

Students, if they are unable to conceptualise the content, tend to feel themselves incompetent and unsatisfied with their performance, and then, as a consequence, most likely do not see the relevance of learning science subjects and their application to everyday life, now or in the future $[14,30]$. This study shows that chemistry, as a separate discipline, stands out compared with other subjects as being more abstract and less linked to everyday life. It allows a prediction that students at the age of 15 do not feel sufficiently able to deal with abstract phenomena. However, the concept of energy taught in physics, which is also among the abstract learning areas, is nevertheless more meaningful in the minds of students. There is a need to investigate, in more depth, the improvement of abstract learning by linking it with everyday settings, which would be applicable in many countries.

\section{Conclusions}

The results from the current study indicated declining tendencies among students' opinions towards learning science. It became evident that students in grade 6 held higher opinions related to the learning of school science as a subject compared with the 15-year-old students in grade 9, even though school subject related themes had little relevance for students at both levels. 
The results showed significant grade and science subjects' differences within the intrinsic motivation sub-scales. Results indicated that the 15-year-old, grade 9 students' motivation to learn was dependent on the science subject-there was a tendency for students' intrinsic motivation to learn biology and geography to be higher than those for the subjects of chemistry and physics considering interest/enjoyment, perceived competence and value/usefulness sub-scales. Biology was generally perceived as the most interesting/enjoyable subject, having high value for learning. Geography was also generally valued as giving a feeling of competence to a similar extent as biology, but students indicated much less interest/enjoyment towards geography learning. Chemistry and physics are perceived as the least interesting/enjoyable subjects for most 15-year-old students involved in the study, although students indicated that, in general, they valued physics learning at almost the same level as geography and biology.

The above stated conclusions can be the base for discussions, applicable to countries where science is taught as separate disciplines for 15-year-old students. The abstractness of the themes in physics and chemistry most probably influence students' motivation to learn and their attitudes towards those subjects. This research indicates the ongoing issues in learning physics and chemistry from a subject, rather than an everyday life, context. Furthermore, considering the issues arising in this research, science learning can be made more relevant to students if the content is more interdisciplinary and the decreasing attitude towards science subjects by 15 -year-old students can be minimised, with the result that better outcomes are enabled in future PISA studies.

\section{Suggestions and Implications}

The current study suggests several implications for educators and teachers regarding improvements in student motivation and opinions on learning science. It indicates the importance of ensuring the relevance of science learning through the use of more personal and social-related contexts, especially in the case of chemistry. As the current trends are towards more integration of subjects (e.g., shifting from STEM, Science, technology, engineering, and mathematics to STEAM, Science, technology, engineering, arts, and mathematics; [19]), more consideration can be given to utilising the same personal and social learning areas in the teaching of Biology, and/or Geography, and/or Chemistry, and/or Physics.

Enhancing students' motivation in learning science (especially towards chemistry) can help teachers better engage with their students, meet their students' needs and use appropriate teaching and learning materials and practices. Future research should be focused on finding out the aspects of age, gender and teaching and learning approaches on students' motivation for science subjects learning.

\section{Limitations}

This study has some limitations:

1. Self-reported questionnaires typically measure the frequencies of students' opinions, or perceptions, but they have their weaknesses. Students' opinions on learning science themes and intrinsic motivation towards science may not entirely reflect the reality of students' thinking - there are a number of different factors that can affect students' perceptions while they are answering the questionnaire and which cannot be taken into account (i.e., teachers' influence, students' ability to concentrate).

2. The first section of the instrument includes a limited range of science themes; thus, the results of the study cannot be generalized to the rest of the science content included in the curricula.

Author Contributions: Conceptualization, M.T., R.S. and M.R.; formal analysis, M.T.; methodology, M.T.; visualization, M.T.; writing—original draft preparation, M.T.; supervision, R.S. and M.R.; writing-review and editing, R.S. and M.R. All authors have read and agreed to the published version of the manuscript. 
Funding: This research was funded by the Estonian Research Council through an institutional research funding project "Smart technologies and digital literacy in promoting a change of learning" (Grant Agreement No. IUT34-6).

Institutional Review Board Statement: Ethical review and approval were waived for this study, due to the study being part of a project for which ethical approval had been obtained from the University of Tartu.

Informed Consent Statement: Informed consent was obtained from all subjects involved in the study.

Data Availability Statement: Data available on request due to restrictions eg privacy or ethical. The data presented in this study are available on request from the corresponding author. The data are not publicly available due to privacy protection of participants.

Acknowledgments: The authors are thankful for all partners, grade 6 and 9 students, science teachers and members of the research team who supported our study.

Conflicts of Interest: The authors declare no conflict of interest.

\section{References}

1. Bandura, A. Perceived Self-Efficacy in Cognitive Development and Functioning. Educ. Psychol. 1993, 28, 117-148. [CrossRef]

2. Pintrich, P.R.; Zusho, A. The Development of Academic Self-Regulation: The Role of Cognitive and Motivational Factors. In Development of Achievement Motivation; Educational Psychology; Wigfield, A., Eccles, J.S., Eds.; Academic Press: San Diego, CA, USA, 2002; pp. 249-284. [CrossRef]

3. Potvin, P.; Hasni, A. Interest, Motivation and Attitude towards Science and Technology at K-12 Levels: A Systematic Review of 12 Years of Educational Research. Stud. Sci. Educ. 2014, 50, 85-129. [CrossRef]

4. Vedder-Weiss, D.; Fortus, D. Adolescents' Declining Motivation to Learn Science: Inevitable or Not? J. Res. Sci. Teach. 2011, 48, 199-216. [CrossRef]

5. Osborne, J.; Simon, S.; Collins, S. Attitudes towards Science: A Review of the Literature and Its Implications. Int. J. Sci. Educ. 2003, 25, 1049-1079. [CrossRef]

6. Liou, P.-Y.; Wang, C.-L.; Lin, J.J.H.; Areepattamannil, S. Assessing Students' Motivational Beliefs about Learning Science across Grade Level and Gender. J. Exp. Educ. 2020, 1-20. [CrossRef]

7. Salta, K.; Koulougliotis, D. Assessing Motivation to Learn Chemistry: Adaptation and Validation of Science Motivation Questionnaire II with Greek Secondary School Students. Chem. Educ. Res. Pract. 2015, 16, 237-250. [CrossRef]

8. Saleh, S. Malaysian Students' Motivation towards Physics Learning. Eur. J. Sci. Math. Educ. 2014, 2, $223-232$.

9. Ekici, G. Factors Affecting Biology Lesseon Motivation of High School Students. Procedia Soc. Behav. Sci. 2010, 2, $2137-2142$. [CrossRef]

10. Kişoğlu, M. An Examination of Science High School Students' Motivation towards Learning Biology and Their Attitude Towards Biology Lesson. Int. J. High. Educ. 2018, 7, 151-162. [CrossRef]

11. Aydın, F.; Coşkun, M. Secondary School Students' “Achievement Motivation” towards Geography Lessons. Arch. Appl. Sci. Res. 2011, 3, 121-134.

12. PISA, OECD Publishing. PISA 2015 Results (Volume I): Excellence and Equity in Education; PISA, OECD Publishing: Paris, France, 2016.

13. Ryan, R.M.; Deci, E.L. Intrinsic and Extrinsic Motivations: Classic Definitions and New Directions. Contemp. Educ. Psychol. 2000, 25, 54-67. [CrossRef] [PubMed]

14. Priniski, S.J.; Hecht, C.A.; Harackiewicz, J.M. Making Learning Personally Meaningful: A New Framework for Relevance Research. J. Exp. Educ. 2018, 86, 11-29. [CrossRef] [PubMed]

15. Corno, L.; Mandinach, E.B. The Role of Cognitive Engagement in Classroom Learning and Motivation. Educ. Psychol. 1983, 18, 88-108. [CrossRef]

16. Lamanauskas, V.; Gedrovics, J.; Raipulis, J. Senior Pupils' Views and Approach to Natural Science Education in Lithuania and Latvia. J. Balt. Sci. Educ. 2004, 1, 13-23.

17. Lannes, D.; Rumjanek, V.M.; Velloso, A.; Lannes, D.; de Meis, L. Brazilian Schools: Comparing Students' Interests with What Is Being Taught. Educ. Res. 2002, 44, 157-179. [CrossRef]

18. Cēdere, D.; Jurgena, I.; Targamadze, V. Interest of Latvian and Lithuanian Students in Science and Mathematics. J. Balt. Sci. Educ. 2018, 17, 31-42.

19. Hazelkorn, E.; Ryan, C.; Beernaert, Y.; Constantinou, C.P.; Deca, L.; Grangeat, M.; Karikorpi, M.; Lazoudis, A.; Casulleras, R.P.; Welzel, M.; et al. (Eds.) Science Education for Responsible Citizenship: Report to the European Commission of the Expert Group on Science Education; Publications Office of the European Union: Luxembourg, 2015.

20. Brophy, J.E. Motivating Students to Learn; Routledge: London, UK, 2010.

21. Mubeen, S.; Reid, N. The Measurement of Motivation with Science Students. Eur. J. Educ. Res. 2014, 3, 129-144. [CrossRef]

22. Palmer, D. A Motivational View of Constructivist-Informed Teaching. Int. J. Sci. Educ. 2005, 27, 1853-1881. [CrossRef]

23. Ryan, R.M.; Deci, E.L. Self-Determination Theory and the Facilitation of Intrinsic Motivation, Social Development, and Well-Being. Am. Psychol. 2000, 55, 68-78. [CrossRef] 
24. Ryan, R.M.; Deci, E.L. Self-Determination Theory: Basic Psychological Needs in Motivation, Development, and Wellness; Guilford Press: New York, NY, USA, 2017; p. 756.

25. Leong, K.E.; Tan, P.P.; Lau, P.L.; Yong, S.L. Exploring the Relationship between Motivation and Science Achievement of Secondary Students. Pertan. J. Soc. Sci. Humanit. 2018, 26, 2243-2258.

26. Ames, C. Classrooms: Goals, Structures, and Student Motivation. J. Educ. Psychol. 1992, 84, 261-271. [CrossRef]

27. Wigfield, A.; Eccles, J.S. Expectancy-Value Theory of Achievement Motivation. Contemp. Educ. Psychol. 2000, 25, 68-81. [CrossRef] [PubMed]

28. Reeve, J. The Interest-Enjoyment Distinction in Intrinsic Motivation. Motiv. Emot. 1989, 13, 83-103. [CrossRef]

29. Ainley, M.; Hidi, S. Interest and Enjoyment. In International Handbook of Emotions in Education; Educational Psychology Handbook Series; Routledge/Taylor \& Francis Group: New York, NY, USA, 2014; pp. 205-227.

30. Harackiewicz, J.M.; Smith, J.L.; Priniski, S.J. Interest Matters: The Importance of Promoting Interest in Education. Policy Insights Behav. Brain Sci. 2016, 3, 220-227. [CrossRef]

31. Bandura, A. Social Foundations of Thought and Action: A Social Cognitive Theory; Prentice-Hall, Inc.: Englewood Cliffs, NJ, USA, 1986; p. 617.

32. Goodman, S.; Jaffer, T.; Keresztesi, M.; Mamdani, F.; Mokgatle, D.; Musariri, M.; Pires, J.; Schlechter, A. An Investigation of the Relationship between Students' Motivation and Academic Performance as Mediated by Effort. S. Afr. J. Psychol. 2011, 41, $373-385$. [CrossRef]

33. Pace, C.R. Measuring the Quality of College Student Experiences. An Account of the Development and Use of the College Student Experiences Questionnaire; Spencer Foundation: Chicago, LA, USA, 1984; p. 142.

34. Pass, M.W.; Abshire, R.D. The Importance of Student Effort and Relationships with Goals Orientations and Psychological Needs. Acad. Educ. Leadersh. J. 2015, 19, 15-30.

35. Fraser, W.J.; Killen, R. The Perceptions of Students and Lecturers of Some Factors Influencing Academic Performance at Two South African Universities. Perspect. Educ. 2005, 23, 25-40.

36. Sturm, H.; Bogner, F.X. Student-Oriented versus Teacher-Centred: The Effect of Learning at Workstations about Birds and Bird Flight on Cognitive Achievement and Motivation. Int. J. Sci. Educ. 2008, 30, 941-959. [CrossRef]

37. Teppo, M. Grade Nine Students' Opinions Relating to the Relevance of Science Education. Master's Thesis, University of Tartu, Tartu, Estonia, 2004. Available online: https://dspace.ut.ee/bitstream/handle/10062/1057/Teppo.pdf?sequence=5\&isAllowed= y (accessed on 15 September 2020).

38. Teppo, M.; Semilarski, H.; Soobard, R.; Rannikmäe, M. 9. Klassi Õpilaste Huvi Eri Kontekstis Esitatud Loodusteaduslike Teemade Oppimise Vastu ja Motivatsioon Õppida Loodusteadusi. Eesti Haridusteaduste Ajak. Est. J. Educ. 2017, 5, 130-170. [CrossRef]

39. Deci, E.L.; Ryan, R.M. Intrinsic Motivation Inventory (IMI). Available online: https://selfdeterminationtheory.org/intrinsicmotivation-inventory / (accessed on 8 January 2016).

40. Leng, E.Y.; Baki, R.; Mahmud, R. Stability of the Intrinsic Motivation Inventory (IMI) for the Use of Malaysian Form One Students in ICT Literacy Class. EURASIA J. Math. Sci. Technol. Educ. 2010, 6, 215-226. [CrossRef]

41. Liu, W.-C.; Wong, A.F.L.; Divaharan, S.; Peer, J.; Quek, C.-L.; Williams, M.D. Students' Intrinsic Motivation in Project-Based Learning Using an Asynchronous Discussion Platform. Educ. Res. J. 2006, 21, 217-234.

42. Meyer, A.; Meyer-Ahrens, I.; Wilde, M. The Beneficial Effects of Non-Received Choice: A Study on Intrinsic Motivation in Biology Education. Eur. J. Educ. Res. 2013, 2, 185-190. [CrossRef]

43. Teppo, M.; Saulep, M.; Soobard, R.; Rannikmäe, M. Factors Influencing Lower Secondary Schools Students' Motivation to Learn Science and Mathematics. INTED2020 Proceedings. 2020, pp. 6165-6173. Available online: https://library.iated.org/view/ TEPPO2020FAC. (accessed on 30 December 2020).

44. Aalsvoort, J. Logical Positivism as a Tool to Analyse the Problem of Chemistry's Lack of Relevance in Secondary School Chemical Education. Int. J. Sci. Educ. 2004, 26, 1151-1168. [CrossRef]

45. Jack, B.M.; Lin, H. Making Learning Interesting and Its Application to the Science Classroom. Stud. Sci. Educ. 2017, 53, 137-164. [CrossRef]

46. Walkington, C.; Bernacki, M. Motivating Students by “Personalizing” Learning around Individual Interests: A Consideration of Theory, Design, and Implementation Issues. In Advances in Motivation and Achievement; Emerald Group Publishing Limited: Bingley, UK, 2014; Volume 18. [CrossRef]

47. Stuckey, M.; Hofstein, A.; Mamlok-Naaman, R.; Eilks, I. The Meaning of 'Relevance' in Science Education and Its Implications for the Science Curriculum. Stud. Sci. Educ. 2013, 49, 1-34. [CrossRef]

48. House, J.D. Classroom Instructional Strategies and Science Career Interest for Adolescent Students in Korea: Results from the TIMSS 2003 Assessment. J. Instr. Psychol. 2009, 36, 13-19.

49. Ausubel, D.P.; Novak, J.D.; Hanesian, H. Educational Psychology: A Cognitive View; Holt, Rinehart and Winston: New York, NY, USA, 1978.

50. Pedaste, M.; Must, O.; Leijen, Ä.; Mäeots, M.; Siiman, L.; Kori, K.; Adov, L. Nutiseadmete Kasutamise Profiilid Loodusainete Ja Matemaatika Õppimise Kontekstis. Eest. Haridusteaduste Ajak. Est. J. Educ. 2017, 5, 99-129. [CrossRef]

51. Schreiner, C.; Sjøberg, S. Sowing the Seeds of ROSE: Background, Rationale, Questionnaire Development and Data Collection for ROSE (The Relevance of Science Education): A Comparative Study of Students' Views of Science and Science Education. Acta Didact. 2004, 4, 126. 
52. Sjøberg, S.; Schreiner, C. The ROSE Project. An Overview and Key Findings. Available online: https://roseproject.no/network/ countries/norway/eng/nor-Sjoberg-Schreiner-overview-2010.pdf (accessed on 21 October 2020).

53. National Curriculum for Basic Schools. Riigi Teataja, 2011/2014. Available online: https://www.riigiteataja.ee/en/eli/52409201 4014/consolide (accessed on 16 September 2020).

54. Hair, J.F.; Black, W.C.; Babin, B.J.; Anderson, R.E. Multivariate Data Analysis; Pearson Education Limited: Harlow, UK, 2013.

55. Kline, R.B. Principles and Practice of Structural Equation Modeling; Guilford Publications: New York, NY, USA, 2011.

56. Muthén, L.K.; Muthén, B.O. Mplus User's Guide. Eighth Edition. Available online: https://www.statmodel.com/download/ usersguide/MplusUserGuideVer_8.pdf (accessed on 2 October 2020).

57. Field, A. Discovering Statistics Using IBM SPSS Statistics, 4th ed.; Sage Publications Ltd.: London, UK, 2013. 